\title{
Persuasi Dakwah Youtube Pada Mahasiswa Islam di Kota Surabaya Selama Pandemi
}

\author{
Nanik Mujiati, Muhammad Munir, Ivan Sunata \\ STAI Sabilul Muttaqin Mojokerto \\ UIN Sunan Ampel Surabaya \\ Institut Agama Islam Negeri Kerinci \\ Email: nanikmuji2301@gmail.com
}

\begin{abstract}
Youtube can make it easy for the public to enjoy and learn the content. The main target students in the use of youtube are good school materials, physical materials that they don't know about in their everyday lives. The aim of this research is how effective the short video in the story of every person who uses as a reminder because the truth of every Muslim is a reminder to other Muslims. With this research it will be useful for the Da'i in a time of much material and more effective long-term education. This type of research is qualitative that uses phenomenological studies in students, data analysis in this study is data reduction and data synthesization. While the group was observing and interviewing. The result of this research is to reveal about Dakwah Media, Youtube Dakwah Media, Youtube Video Adaptation Dakwah on Khalayak, Social Media and Student Self-Concept and the Dakwah symphony through this youtube can also be enjoyed anywhere and whenever. The subject or the indictment also contains the subject that Surabaya students need. As for this youtube persuasion, it's only about invitations or good advice for Surabaya students. The video's neither long nor boring. Surabaya students can also take wisdom or indictment as indictees say.
\end{abstract}

Keywords: Persuasive Da'wah; Youtube Da'wah Persuasion; Pandemic

Abstrak. Dakwah youtube memberikan sebuah kemudahan kepada masyarakat agar bisa menikmatinya serta mempelajari materi yang ada pada konten tersebut. Mahasiswa sasaran utama dalam penggunaan youtube baik dari materi kuliah, materi fiqih yang belum mereka ketahui dalam kehidupan sehari-hari. Tujuan pada penelitian ini adalah bagaimana efektifitas video pendek yang ada di story setiap person yang berguna sebagai pengingat karena sejatinya setiap muslim adalah pengingat bagi muslim lainnya. Dengan penelitian ini nantinya bisa berguna kepada para da'i di zaman sekarang materi yang banyak dan berdurasi panjang lebih efektif. Jenis penelitian ini adalah kualitatif yang menggunakan studi fenomenologi pada mahasiswa, analisis data dalam penelitian ini adalah reduksi data dan sintesisasi data. Sedangkan pengumpulannya observasi dan interview. Hasil dari penelitian ini adalah mengungkapkan tentang Media Dakwah, Media Dakwah Youtube, Dakwah Persuasi Video Youtube pada Khalayak, Media Sosial dan Konsep Diri Mahasiswa dan simpulan Dakwah melalui youtube ini juga dapat dinikmati dimanapun dan kapanpun. Materi atau pesan dakwah juga memuat topik yang dibutuhkan mahasiswa Surabaya. Adapun dakwah persuasi youtube ini tidak memuat paksaan, melainkan tentang ajakan atau saran yang baik bagi mahasiswa Surabaya. Videonya juga tidak berkepanjangan dan tidak membosankan. Mahasiswa Surabaya juga bisa mengambil hikmah atau pesan dakwah sebagaimana yg disampaikan pelaku dakwah.

Kata kunci: Dakwah Persuasif, Persuasi Dakwah Youtube, Pandemi 


\section{PENDAHULUAN}

Media massa menjadi pendorong serta menjadi sarana dalam sebuah interaksi dan komunikasi. Youtube telah menjadi sebuah hiburan serta persuasif kepada masyarakat khususnya dalam dakwah yang berisi tentang pengetahuan islam. Dakwah youtube memberikan sebuah kemudahan kepada masyarakat agar bisa menikmatinya serta mempelajari materi yang ada pada konten tersebut. Mahasiswa sasaran utama dalam penggunaan youtube baik dari materi kuliah, materi fiqih yang belum mereka ketahui dalam kehidupan sehari-hari.

Kebutuhan masyarakat memberikan sebuah pesan khusus kepada para da'i, pesan tersebut berupa pemilihan metode dalam berdakwah perlu diketahui, apalagi ceramah seorang da'i akan di upload di youtube, materi yang dipilih pun harus sesuai dengan kondisi masyarakat saat ini. Salah satu contoh da'i yang bisa membawa suasana menarik kepada mahasiswa ialah ustadz Handy Bonny dengan metode millenial serta sering mengajak para kaum muda untuk berhijrah. Maka dalam berdakwah di youtube hal yang menarik sebenarnya terletak pada kalimat-kalimat yang bisa menyadarkan kaum muda.

Hal ini sesuai dengan data yang di keluarkan oleh hootsuite penggunaan youtube di Indonesia pada Januari 2020 adalah paling banyak, itu artinya Indonesia adalah penyumbang viewer youtube terbanyak. Tentu dengan jumlah tersebut yang terbanyak adalah usia 10-20 tahun. Karena kelabilan dan masih belum memiliki tanggungan. 


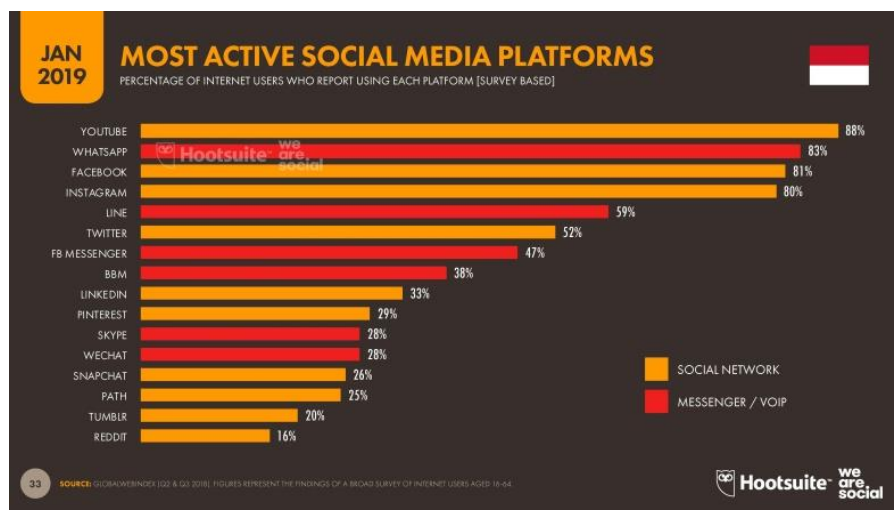

Gambar 01 : Data pengguna media sosial di Indonesia

Fenomena yang terjadi pada mahasiswa saat ini yaitu upload video konten dakwah yang berdurasi pendek untuk dijadikan sebuah story di whatsapp, instagram, facebook, bahkan youtube. Konten tersebut sebenarnya lebih konkrit dari pada ceramah yang full, karena dakwah yang full itu cenderung membuat kebosanan pada pendengar dakwah. Hal ini berarti ada orang ketiga yang membantu da’i menjadi ceramahnya terkenal serta diminati oleh kalangan muda bahkan kalangan dewasa. orang ketiga itu adalah pengedit video.

Dengan adanya pandemi yang terjadi di Indonesia khususnya para mahasiswa dituntut untuk berdiam diri di rumah tanpa melakukan aktivitas diluar rumah. Kegiatan seperti ini lebih banyak pada konten islam karena khalayak lebih banyak menghabiskan kegiatan kesehariannya di dalam rumah dan kamar. Hal ini berdasarkan fenomena yang terjadi pada story whatsapp dan instagram yang rata-rata mahasiswa islam mengupload video berdurasi pendek untuk dijadikan story hal tersebut berguna untuk mempersuasi kebutuhan orang-orang yang masih merasa jauh dengan sang penciptanya.

Tujuan pada penelitian ini adalah bagaimana efektifitas video pendek yang ada di story setiap person yang berguna sebagai pengingat karena sejatinya setiap muslim adalah pengingat bagi muslim lainnya. Dengan penelitian ini nantinya bisa berguna kepada para da'i di zaman sekarang 
materi yang banyak dan berdurasi panjang lebih efektif.

\section{HASIL DAN PEMBAHASAN}

Hasil temuan menunjukkan bahwa terdapat beberapa mahasiswa Islam Surabaya yang setelah menyaksikan dakwah melalui media Youtube yang mudah diakses dan fleksibel tersebut, seperti penjelasan informan:

"Dengan youtube saya bisa menggunakannya secara bebas dan tidak terikat waktu" (informan 1).

Dakwah di youtube, sedikit demi sedikit dapat menggugah perasaan audiens untuk mendekatkan diri kepada Allah swt dan bisa mengambil hikmah yang disampaikan da’i. sebagaimana ungkapan informan:

"Karena saya juga ingin menyaksikan konten dakwah dan mendekatkan diri kepada Allah, kemudian tak ambil bikmabnya" (informan 1).

Selain itu, pesan dakwah sangat penting untuk dipahami terutama dakwah yang disiarkan melalui media youtube, selama pandemik ini.

"Sekarang kan musim corona, sehingga saya sering dirumah dan tidak berani keluar rumah. Dengan itu saya luangkan waktu membuka youtube seperti konten dakwah yang bermacam-macam. Karena menurut saya itu juga penting buat memahami dakwah" (informan 2).

"Saya mengakses youtube juga untuk menyaksikan dakwah. Dakwabnya dikemas dengan baik di youtube dan lebih jelas juga. Materinya juga menarik"” (informan 3).

Hal tersebut menunjukkan bahwa selama mengakses dakwah di youtube, ia memperoleh kesan bahwa kontennya sangat menarik dan dikemas dengan baik.

"Dakwah melalui youtube dapat saya undub dan disimpan untuk lebib saya pahami lagi” (informan 3).

Penjelasan di atas mengungkapkan bahwa dakwah yang disiarkan melalui youtube itu sangat efektif untuk disimpan penggunanya terutama di era saat ini, dimana masyarakat harus mematuhi aturan baru selama pandemik dengan tidak berkerumun.

Maka, dapat disimpulkan bahwa adanya penggunaan media dakwah youtube dapat meningkatkan kepuasan pesan dakwah bagi penggunanya. 
Sementara itu, alasan mengakses media youtube ialah karena media tersebut mudah diakses dan dijangkau tanpa batas waktu. Berdasarkan hasil temuan, diketahui bahwa kebanyakan mahasiswa/i Surabaya mengakses dakwah melalui video karena lebih fleksibel, serta tayangannya lebih menarik terutama berbentuk film. Selain itu, siarannya juga dapat diputar ulang sehingga lebih mudah bagi informan dalam memahami pesan dakwah.

Pesan dakwah yang diperoleh mahasiswa/i Surabaya ialah terkait dengan ajaran agama Islam. Melalui media dakwah youtube, informan secara perlahan mulai memahami perbuatan baik dan buruk dalam ajaran agama Islam, serta yang harus dilakukan dan dilarang. Sebagaimana ungkapan informan dibawah ini:

"Pesan dakwahnya menarik. Biasanya tentang permasalahan di masyarakat. Hal apa yang dilarang dan dianjurkan dalam Islam" (Informan 1).

Ungkapan ini tidak jauh berbeda dengan ungkapan informan lain, bahwa materi atau pesan dakwah tentang amar ma'ruf nabi munkar hal apa yang dianjurkan dan dilarang bagi umat Muslim.

"Pesannya tentang amar ma'ruf nahi munkar" (Informan 2).

Dengan demikian, media youtube dapat membantu mereka dalam mempelajari dan memperlancar pemahaman informasi tentang apapun yang ingin diketahui terkait pesan dakwah. Meskipun terdapat beberapa jenis media dakwah, namun kelebihan dari media dakwah youtube ini ialah seperti dapat diakses dengan mudah dan bisa dibawa kemana-mana (fleksibel) oleh mahasiswa-mahasiswi Surabaya.

\section{Media Dakwah}

Dakwah secara etimologis berasal bahasa Arab yaitu da'a-yad'u-da'watan, yang artinya mengajak, menyeru, dan memanggil. Secara terminologi diungkapkan secara langsung oleh Allah SW'T dalam ayat Al-Qur'an. Kata dakwah di dalam Al-Qur'an diungkapkan sekitar 198 kali yang tersebar dalam ayat 55 surat (176 ayat). Di sisi lain, secara terminologi para ahli memiliki 
pendapat yang berbeda-beda dalam memaknai kata dakwah.

Secara normatif, Adi Sasono menyatakan dakwah yaitu mengajak manusia ke jalan kebaikan dan petunjuk untuk memperoleh kebahagiaan di dunia dan akhirat atau merupakan transformasi sosial. Sedangkan Ali Makhfudh dalam kitabnya Hidayatul Mursyidin mengungkapkan bahwa dakwah adalah mendorong manusia untuk berbuat kebajikan dan mengikuti petunjuk (agama), menyeru mereka kepada kebaikan dan mencegah kemungkaran agar memperoleh kebahagiaan dunia dan akhirat. Kemudian, Quraish Shihab pula mengatakan yang dimaksud dakwah adalah seruan atau ajakan kepada keinsafan atau usaha mengubah situasi kepada situasi yang lebih baik dan sempurna, baik terhadap pribadi ataupun masyarakat ( $A B$, 2016, h. 6-9).

Berdasarkan uraian yang tertera mengenai makna dari dakwah, dapat dikatakan bahwa dakwah merupakan upaya yang dilakukan untuk menyampaikan sesuatu kepada individu maupun masyarakat yang bernilai kebaikan dalam menjalani kehidupan sehari-hari. Dalam Islam, dengan adanya dakwah diupayakan dapat terbentuk masyarakat berlandaskan ajaran Al-Qur'an dan Hadits. Sehingga tercipta pula masyarakat madani yang senantiasa berpegang teguh kepada ajaran agama Islam.

Sedangkan media berasal dari bahasa Latin "Medius" yang berarti perantara, tengah atau pengantar. Dalam bahasa Inggris, media merupakan bentuk jamak dari medium yang artinya tengah, antara, rata-rata. Dari pengertian tersebut, ahli komunikasi mengartikan media sebagai alat yang menghubungkan pesan komunikasi yang disampaikan oleh komunikator (pengirim pesan) kepada komunikan (penerima pesan). Sedangkan di dalam bahasa Arab, media sama halnya dengan wasilab (وسيلة) atau dalam bentuk jamak, wasail (وساءل) artinya alat atau perantara (Aziz, 2017, h. 345).

Para ahli masing-masing memiliki pendapat yang berbeda dalam memaknai media dakwah. Abdul Kadir Munsyi menyatakan media dakwah 
adalah alat yang menjadi saluran yang menghubungkan ide dengan umat. Hamzah Ya'qub menganggap media dakwah merupakan alat objektif yang menjadi saluran yang menghubungkan ide dengan umat. Sedangkan AlBayanuni menyatakan bahwa media dakwah adalah sesuatu yang bersifat fisik dan non-fisik yang bisa mengantarkan pendakwah dalam menerapkan strategi dakwah (Aziz, 2017, h. 346). Berdasarkan definisi mengenai media dakwah oleh para ahli, dapat diketahui bahwa media dakwah adalah alat yang menjadi perantara penyampaian pesan dakwah kepada mitra dakwah (mad'u).

\section{Media Dakwah Youtube}

Pada dasarnya banyak alat yang bisa dijadikan sebagai media dakwah. Setiap alat itu tergantung dari tujuannya. Abdul Kadir Munsyi mencatat bahwa terdapat enam jenis media dakwah yakni lisan, tulisan, lukisan atau gambaran, audio visual, perbuatan, dan organisasi. Asmuni Syukir mengelompokkan media dakwah menjadi enam macam, yaitu lembagalembaga pendidikan formal, lingkungan keluarga, organisasi-organisasi Islam, hari-hari besar Islam, media massa, dan seni budaya. Sedangkan Muhammad Ali Hasyim menyebut media dakwah dan sarana dakwah atau alat dakwah dan medan dakwah ada enam macam, yaitu mimbar (podium) dan khitabah (pidato/ceramah), qalam (pena) dan kitabah (tulisan), masrah (pementasan) dan malhamah (drama), seni suara dan seni bahasa, madrasah dan dayah (surau), serta lingkungan kerja dan usaha (Aziz, 2017, h. 347).

Media dakwah yang dituangkan didalam Al-Qur'an yakni media persepsi (hati, pengetahuan asumtif, kecerdasan) dan media sensasi yang paling dominan adalah media auditif dan media visual. Dari hubungan kedua media ini lahir tiga macam media, yaitu media auditif, media visual, dan media audio visual. Media auditif seperti radio dan casette/ tape recorder. Media visual adalah sarana yang dapat ditangkap oleh mata manusia. Hampir semua media dakwah didominasi oleh media ini. Contoh dari media visual yaitu pers, surat, poster atau plakat, buku, internet, sms, dan brosur. Sedangkan 
media audiovisual merupakan gabungan dari media auditif dan media visual. Kekurangan dalam media auditif maupun media visual dapat diatasi dengan media audiovisual. Media audiovisual seperti televisi, film, video, sinema, dan sejenisnya (Aziz, 2017, h. 351).

Adapun media dakwah audiovisual dalam ini ialah youtube. Youtube adalah penyedia layanan video terbesar saat ini dan merupakan media yang secara gratis untuk upload. Secara gratis, pengguna dapat memuat, menonton, dan berbagi klip video. Youtube juga sangat cocok untuk mencari informasi tanpa harus membaca artikel. Video-video yang ditayangkan melalui youtube adalah video klip, acara TV, film, serta video buatan para pengguna itu sendiri.

Manfaat dari penggunaan youtube adalah kontennya dapat disiarkan kepada jutaan khalayak. Hampir setiap negara di dunia dan setiap komputer yang terakses internet menyediakan media sosial youtube. Youtube merupakan tempat berbagi data (file) bagi setiap membernya, dan khalayak dapat mencari atau upload video rekaman orang lain untuk dapat disaksikan mereka yang mengaksesnya. Dari segi dakwah, kebutuhan publik terhadap video yang berdurasi pendek sangat tinggi. Mereka mengakses video guna memenuhi kebutuhannya (Habibi, 2018, h. 113).

Media sosial youtube yang semakin berkembang memberikan arahan baru bagi terciptanya model dakwah dengan format berbagi link atau video. Selama ini dakwah atau pengajian secara konvensional membutuhkan ruang dan waktu tertentu, namun dengan adanya youtube kemungkinan besar masyarakat mudah dan cepat memperoleh konten dakwah atau kajian dimanapun dan kapanpun. Selain itu, pengguna youtube juga dapat memilah dan memilih da'i atau topik sesuai kebutuhan (Cahyono \& Hassani, 2019, h. 30).

\section{Dakwah Persuasi Video Youtube Pada Khalayak}

Dari waktu ke waktu media social salah satunya youtube telah 
mengalami perkembangan dan banyak kalangan pendakwah menggunakan media tersebut untuk berdakwah. Hal ini diketahui banyaknya jutaan followers (pengikut) akun-akun dakwah di youtube. Followers ini tidak hanya kalangan masyarakat dalam negeri, namun pula luar Negara Indonesia.

Dakwah yang disampaikan melalui media social youtube tidak jauh berbeda dengan dakwah secara langsung di tempat (pengajian), yang mana dakwahnya menggunakan bahasa persuasi. Istilah persuasi artinya membujuk atau menyarankan. Awal mulanya persuasi menjelaskan gagasan disertai sebab, bukti, maupun contoh guna meyakinkan khalayak. Selanjutnya diikuti seruan, ajakan, bujukan, hingga saran terhadap khalayak (Wiyanto, 2004, h. 68). Adapun tujuan dari persuasi menurut Kosasih ialah untuk mempengaruhi pembaca atau khalayak (Kosasih, 2003, h. 9).

Ciri-ciri persuasi diantaranya ialah: Pertama, harus menyebabkan rasa percaya pendengar atau pembaca. Kedua, bertolak dari pendirian bahwa pemikiran manusia dapat diubah. Ketiga, dapat menciptakan penyesuaian melalui rasa kepercayaan kedua pihak yaitu penulis atau pembaca dengan yang mendengar atau membaca. Keempat, harus diupayakan menghindari konflik supaya kepercayaan tidak hilang sehingga tujuan tercapai. Kelima, Serta, didalamnya memuat fakta, bukti, dan data yang cukup.

Sedangkan bentuk persuasi dapat berupa: Pertama, pidato, seperti propaganda, kampanye, dan lain-lain di tempat terbuka atau umum. Kedua, tulisan, misalnya iklan. Ketiga, elektronik, seperti internet dan televisi (Harista, 2017, h. 63).

Dengan demikian yang disebut dengan dakwah persuasi ialah dakwah yang memuat ajakan, seruan maupun himbauan oleh pelaku dakwah terhadap khalayak (mad'u) untuk amar ma'ruf nahi munkar atau tetap dijalan Allah. Melalui dakwah persuasi diharapkan dapat menimbulkan adanya perubahan bagi khalayak sebagaimana tujuan pelaku dakwah.

Akan tetapi, di sisi lain pelaku dakwah juga ditantang dalam 
menghadapi kondisi objek dakwah yang bermacam-macam, sehingga pendekatan persuasinya juga berbeda-beda. Dakwah menjadi sifatnya persuasi dapat muncul dari unsur pribadi pelaku dakwah, materi dakwah, dan kondisi psikologis objek dakwah, maupun perpaduan antara ketiganya (Slamet, 2009, h. 182).

Sementara itu, dakwah persuasi video youtube di masa sekarang menjadi popular di tengah masyarakat. Pelaku dakwah dituntut untuk mengikuti perkembangan teknologi dengan memanfaatkan media youtube tersebut. Adapun penyampaian bahasa dakwah persuasi yang dikemukakan melalui youtube seperti penyampaian dengan wibawa oleh da'i, pemberian harapan masa depan, memberikan peringatan, realistis dan logika yang kuat.

\section{Media Sosial dan Konsep Diri Mahasiswa}

Wadah yang sangat signifikan dalam membantu perkembangan identitas diri adalah dengan menggunakan media sosial, hal ini bisa dilihat dari bagaimana mahasiswa menggunakannya. Melalui media sosial, remaja memiliki komunitas online yang memberikan kesempatan bagi remaja untuk berinteraksi secara sosial dengan orang lain dan mendapatkan umpan balik tentang dirinya dari komunitas tersebut (Nurhalimah, 2019). Umpan balik dan evaluasi diri dari komunitas dunia maya ini dianggap penting bagi individu untuk dijadikan pedoman membentuk konsep dirinya. Selain itu, komunikasi melalui dunia maya tidak terlalu membebani dan menakutkan bagi remaja karena remaja dapat mengganti karakternya secara mudah pada media sosial. Dengan kata lain, bagi para remaja komunikasi dunia maya melalui media sosial dianggap sebagai tempat ideal untuk bereksperimen dan melakukan eksplorasi pencarian identitas. Dikarenakan kemudahan dalam menjelajahi dunia media sosial, remaja mengakses media sosial secara terus menerus dan seringkali menimbulkan fenomena penggunaan berlebihan atau ketagihan (addiction). 


\section{PENUTUP}

Dakwah di era sekarang lebih berorientasi pada teknologi yang lebih maju dan berkembang, salah satunya media sosial youtube. Persuasi Youtube sangatlah signifikan untuk memberikan pengaruh pada khalayak. Youtube menjadi sekian dari beberapa media sosial yang dimanfaatkan untuk berdakwah. Dakwah ini disebut dengan dakwah persuasi. Berdasarkan hasil temuan, diketahui bahwa dakwah melalui video youtube lebih efektif dan simple terutama di era pandemi saat ini. Khususnya pada mahasiswa Surabaya yang mengakses youtube dapat dengan mudah membuka konten dakwah di media sosial tersebut. Dalam hal ini meminimalisir kerumunan di tempat terbuka seperti biasanya, apalagi adanya situasi pandemi seperti saat ini.

Dakwah melalui youtube ini juga dapat dinikmati dimanapun dan kapanpun. Materi atau pesan dakwah juga memuat topik yang dibutuhkan mahasiswa Surabaya. Adapun dakwah persuasi youtube ini tidak memuat paksaan, melainkan tentang ajakan atau saran yang baik bagi mahasiswa Surabaya. Videonya juga tidak berkepanjangan dan tidak membosankan. Mahasiswa Surabaya juga bisa mengambil hikmah atau pesan dakwah sebagaimana yg disampaikan pelaku dakwah.

Untuk semua peneliti selanjutnya agar dapat mengembangkan kajian keilmuan dakwah dan media. Karena penelitian ini pastinya memiliki kelebihan dan kekurangan. Maka untuk penelitian selanjutnya supaya fokus pada penelitian media massa dan strategi dakwah jaman now.

\section{DAFTAR REFERENSI}

AB, S. (2016). Pengantar Sosiologi Dakwah. Kencana.

Aziz, M. A. (2017). Ilmu Dakwah. Kencana.

Cahyono, G., \& Hassani, N. (2019). Youtube: Seni Komunikasi Dakwah dan Media Pembelajaran. Al-Hikmah, 13(1). 
Habibi, M. (2018). Optimalisasi Dakwah Melalui Media Sosial di Era Milenial. Al-Hikmah, 12(1).

Harista, E. (2017). Penggunaan Bahasa Persuasi Di Media Sosial Dalam Berdakwah Pada Akun Facebook Yusuf Mansur (Official). Mawa’iz̧, $8(2)$.

Kosasih, E. (2003). Kompetensi Ketatabahasaan dan Kesusastraan. Yrama Widya.

Nurhalimah, S. dkk. (2019). Media Sosial Dan Masyarakat Pesisir : Refleksi Pemikiran Mahasiswa Bidikmisi. CV. Budi Utama.

Slamet. (2009). Efektifitas Komunikasi dalam Dakwah Persuasif. Jurnal Dakwah, 10(2), 182.

Wiyanto, A. (2004). Terampil Menulis Paragraf. PT. Gramedia Widiasarana Indonesia. 